\title{
Influence of functional environmental processes on selected coastal ecosystems of the Gdańsk seashore
}

\author{
Wojciech Staszek \\ University of Gdańsk, Faculty of Oceanography and Geography, Institute of Geography, \\ Department of Physical Geography and Environmental Management, \\ J. Bażyńskiego 4 St, 80-309 Gdańsk, Poland, \\ e-mail: geosw@ug.edu.pl
}

Received: 31 October 2017 / Accepted: 28 February 2018

\begin{abstract}
The paper discusses the diversity of the main functional processes that determine the formation of specific types of ecosystems in two types of coastal areas: cliffs and lowlands. The survey was conducted in selected areas of the Gdańsk Coast.

In the case of low coasts, the objective was to identify the effects of the sea on the formation of the surface water properties that determine the presence of halophytes. The studies conducted indicate that these properties in brackish areas differ significantly in respect of electrolytic conductivity and chloride content from waters occurring in areas not occupied by halophyte communities. Based on the results obtained, it was found that in the studied coastal zone the occurrence of salt grassland ecosystems is associated with water conductivity above $2,000 \mu \mathrm{S} \cdot \mathrm{cm}^{-1}$ and chloride content above $600 \mathrm{mg} \cdot \mathrm{dm}^{-3}$. These values are many times higher than average values for typical inland waters in the Pomerania area, which clearly indicates the dominant role of the brackish water inflow from the Baltic Sea in shaping the environmental conditions for the occurrence of such ecosystems. At the same time, it was found that high water conductivity and salinity conditions were maintained at a distance of about 100-250 m (Władysławowo) to more than $600 \mathrm{~m}$ from the seacoast (Beka). This differentiation depends both on the local conditions of seawater intrusion inland and on the intensity of inland surface and ground water inflows.

In the case of cliff shores, the results of soil and habitat identification and their relationships with the dynamics of morphodynamic processes (abrasion, slope processes) were summarised. On this basis, the characteristics of the main types of cliff ecosystems (initial grassland communities, scrub with sea buckthorns, low stemmed scrub and sycamore forests) were presented. The results indicate that the varying intensity of the slope processes significantly affects the diversity of soil types and soil properties, including the presence of calcium carbonate and the high $\mathrm{pH}$ values in active cliffs. These features, among others, discriminate the cliff ecosystems commonly found in the Pomerania region.
\end{abstract}

Key words: saline waters, saline ecosystems, halophytes, coastal habitats, cliff ecosystems, Baltic Sea.

\section{Introduction}

The shore area is characterized by a specific nature, resulting largely from the very high intensity and specificity of functional processes related to the impact of the sea on the land. According to Przewoźniak (1991), it is a zone of material-energy impact of the sea, manifested most strongly, for instance, in the changes in the coastline, the formation and continuous shaping of specific types of coasts, as well as in the formation of specific hydrological and hydrochemical conditions associated with ingresses of sea waters into the land area. The activity and dynamics of these processes lead to the development of very specific soil and habitat as well as phytocentric conditions, which determine the distinctness of the ecosystems existing in this area, creating distinct coastal systems, strongly differentiated from the ones occurring on the land surface (Przewoźniak, 1991). 
The specificity of the ecosystems of flat coastland has been quite well been recognized in recent years, especially in relation to the soil and habitat conditions of saline communities (Hulisz, 2013; Hulisz et al., 2016, Piernik \& Hulisz, 2011) and also in the scope of hydrological studies (Błaszkowska et al., 2016; Cieśliński, 2007; Jokiel, 2016). Nevertheless, there is still no comprehensive crosssectional study on the evolution of hydrochemical conditions on these types of coastlines, especially in terms of the properties that predispose specific saline ecosystems and the extent of the influence of the sea on water chemistry.

In turn, the nature of the cliff ecosystems is yet poorly recognized, in terms of a comprehensive, synthetic approach. The studies, so far, carried out have dealt mainly with issues related to plant communities (Chojnacki, 1979; Markowski, 1998; Markowski et al., 1998), rarely to soils (Bednarek, 1979). Only a few of them attempted a somewhat broader overall characterics of the conditions for their development (Piotrowska, 1993, 2003).

The main aim of the study was to analyse the key environmental processes leading to form a very specific set of ecosystems within the Gdańsk seashore - saline habitats with halophytes and cliff ecosystems. Therefore the main environmental determinants of their occurrence were studied and described. The important problem of study was to set water salinity limits determining the occurrence of halophytes habitats, as well as the range of the sea's influence on the mainland forming the appropriate conditions for this. In the case of cliff seashores the most important factor of differentiation of habitats and ecosystems is the morphological activity and, as the result, soil forming processes and main properties of soils.

The studied ecosystems are crucial for the natural values of several number of forms of nature protection in which the researched sites are located, what emphasizes the significant meaning of this subject of study.

\section{Study area}

The research area covers the marine belt of the Gdańsk Coast, situated on the Gulf of Gdańsk and Puck, as well as within the shore area of Kępa Swarzewska. In terms of physical geography (Kondracki, 1994), it represents essentially two mesoregions: Kashubian Coast and Hel Peninsula.

The study area, which was subjected to detailed analysis, covered the following sections of the coast (Fig. 1):

- cliffs: Kolibki (KB), Orłowo (OR), ChłapowoRozewie (CHR), Jastrzębia Góra (JSG);

- lowland coastlines: Mechelinki (MCH), Beka (BK), Władysławowo (WŁ) and Jastarnia (JS).

The cliffs covered diverse parts of postglacial elevations, built primarily from glacial sediments (glacial till) and glaciofluvial deposits (sands and fluvioglacial gravels), and in some places the deposits are marginal. In their lower parts, there is an ancillary share of neogene deposits, mainly quartz sand and silt, and lignite deposits in some places. A total absence of neogene deposits was found in the Kolibki section (KB).

The height of the studied cliffs and the abrasion activity, and therefore, the development of the slope processes, varied. The lowest part of the cliff, up to about $10 \mathrm{~m}$ high, is Kolibki section (KB), whose activity can be assessed as small. The highest and most active cliffs are Orłowo (OR) and Jastrzębia Góra (JSG), with altitudes of up to 30-40 m.

The rate of cliff retreat in Orłowo is estimated at about $0.5 \mathrm{~m} /$ year, while in Jastrzębia Góra, depending on the years, from about 0.45 to appromately $0.9 \mathrm{~m}$ per year (Subotowicz, 1982). The height of the cliffs in ChłapowoRozewie section (CHR) ranges between 40-50 m and even more (Cape Rozewie). This cliff exhibits varied activity, while the section directly at the cape was reinforced with a concrete band, which protects it against the direct effect of abrasion. This section should be regarded as a dead cliff, anthropogenically reinforced.

All of the flat coast sections studied are within the Puck Bay, forming relatively narrow stripes of wetland and peated coastal plains, rising to a small height above sea level, generally not exceeding elevations of approximately $0.5 \mathrm{~m}$ above sea level. In the geological structure, there is a significant share of organogenic sediments - peat, layers of sand and gravel of maritime accumulation, while in the case of Beka surface (BK), the share of river alluvial deposits. The formation of the coastal line and dunes banks is usually very weak - the height does not exceed 1.0-1.5 $\mathrm{m}$. It does not occur on large sections of Beka (BK) and Władysławowo (WŁ), which leads to periodic seawater floods during storm accumulations.

Mechelin area $(\mathrm{MCH})$ is located in the peripheral part of the Red-Łeba Proglacial stream valley, with a slight elevation of moraine plateau. The Beka (BK) area is located in the eastern part of the Red-Łeba Proglacial stream valley and includes the Reda River estuary. Compared to the remaining sections of the studied flat coastline, it is characterized by an active inflow of inland river waters (Reda River). The section of Władysławowo (WŁ) is a narrow belt of coastal lowlands at the junction of Kępa Swarzewska and the base of Hel Peninsula, while the last area, Jastarnia (JS), is a marshy, peat plain developed on the back of the dune banks of Hel Peninsula.

\section{Material and methods}

The study was conducted in different ways depending on the type of coast. In the case of flat coasts (where the impact of brackish marine waters was crucial for the devel- 
opment of specific saline ecosystems) the research was focused on the identification of the characteristics of surface water (Błaszkowska, 1996; Hulisz, 2013; Hulisz et al., 2016). These included measurements of electric conductivity (EC) and water $\mathrm{pH}$ analyses of basic ionic composition. Measurements of electric conductivity and $\mathrm{pH}$ were performed directly during the field research, using a multiparameter WTW pH/Cond 340i meter. Basic ion determinations were made on the ion chromatograph Dionex C-1100 and Dionex-500.

These studies focused on defining hydrological conditions of the occurrence of Juncetum gerardi. Therefore, the representative sampling points of the waters were selected at the sites where the patches of this plant group were found. In addition, it confirmed the presence of halophytes in this area. Simultaneously, for comparative purposes, samples were taken from places where halophytes were not identified. The most important diagnostic species for the occurrence of coastal saltwater on the studied sections of the coast area were the following species: Juncus gerar- $d i$ and Triglochin maritima, more seldom Glaux maritima and Plantago maritima, and occasionally Aster tripolium (found only on Władysławowo - WŁ area). In the area of Jastarnia (JS) no halophyte communities were found, although it is reported in literature (Meissner et al., 1999). Marking of the species in this area was considered representative only for waters of hydrogenic ecosystems, without halophytes.

During the research, data and information on the diversity and occurrence of plant communities and flora, derived from the quoted literature text as well as available archived materials (plans for protecting nature reserves "Kępa Redłowska", "Mechelińskie Łąki", "Beka") were used. The occurrence of halophytes it the studied areas were each time confirmed during terrain research and their position were recorded using GPS.

The examination of waters was conducted in September and October 2016, and in the corresponding period of 2017. A total of 135 water samples were collected and marked, of which 31 complete laboratory analyses were

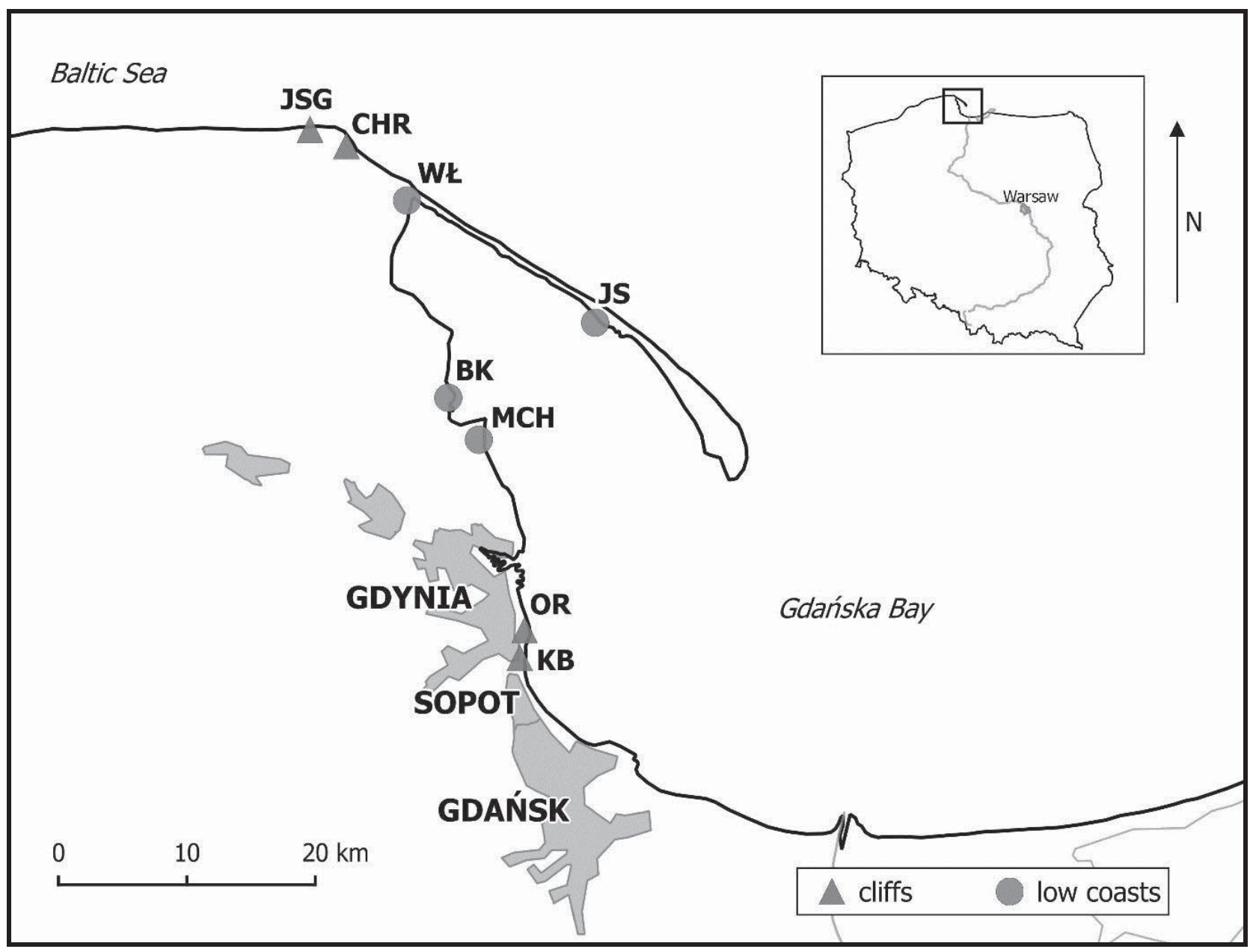

Figure 1. Location of research areas. Cliffs: KB - Kolibki, OR - Orłowo, CHR - Chłapowo-Rozewie, JSG - Jastrzębia Góra. Flat Coast: MCH - Mechelinki, BK - Beka, Władysławowo, JS - Jastarnia 
carried out. Based on the results of the analyzes the hydrochemical types of water were determined according to the method of Szczukariew - Prikłoński (Pazdro \& Kozerski, 1990), on the basis of comparing the percentages of major ions in water, expressed in $\mathrm{mmol}_{\mathrm{c}} \cdot \mathrm{dm}^{-3}$. In addition, the results of measurements and studies of surface and groundwater conducted in the research area (Jokiel, 2012, 2016) were also used for the section of Beka (BK) and Władysławowo (WŁ). Statistical analysis (basic statistic, correlation matrix and regression, mean analyses) was performed using program Statistica 13.0.

In case of cliff coast, analysis of soil, near-surface geological structure, morphometry (gradient of a slope) and morphodynamics (landslides, downhill creeping and flushing) and vegetation have been used as the basis for the identification of the main features of ecosystems. The research was carried out in the system of slope transects, which enables the recognition of the diversity of soils and habitats on selected representative cliff sections.

Field studies of soil and surface geological formations were carried out using a soil probe and making soil pits. They were conducted in order to determine the morphological features of the soil and to identify their typology. Directly in the field, simple $\mathrm{pH}_{(\mathrm{KCl})}$ measurements of individual genetic levels were made using the colorimetric method using acidometer with Hellige's soil acetic acid (measurement accuracy $-0.5 \mathrm{pH}$ ). The content of calcium carbonate on the basis of its reaction with hydrochloric acid was also reported. These studies, most of them of qualitative nature, aimed preliminarily at identifying the main features of soils and habitats. Lack of more detailed quantitative studies prevents extended soil analysis, as well as a precise identification of some soil at diagnostic levels.
Within the range of water studies, on the cliff sections, the measurements were limited to basic water parameters (electric conductivity and $\mathrm{pH}$ reaction). They play a limited, strictly local, role in the formation of specific humid habitats on the slopes of the cliffs.

The studied soils were classified according to Polish Soil Classification (2011). The most appreciate equivalents of soils types and subtypes to the international nomenclature is still the aim of important discussion between Polish pedologist (Kabała et al., 2016; Świtoniak et al., 2016). The names of soil units were therefore taken according to the newest World Reference Base for Soil Resources (WRB) 2015 classification, after Kabała et al. (2016).

\section{Results}

\subsection{Low coast saline ecosystems}

Water studies have shown a clear association of brackish seawaters on the physicochemical properties of waters within the range of saline waters. On the low coasts, which are occupied by halophytes, the presence of highly mineralized waters comprising of $\mathrm{Cl}-\mathrm{Na}-\mathrm{Mg}-$ chloride - sodium - magnesium waters is typical (Fig. 2). These belong to this hydrochemical class and the basic features of these waters are an important diagnostic indicator, clearly demonstrating the influence of marine waters on the hydrological regime of waters within these ecosystems.

In the areas that are slightly off-shore, beyond the zone of salt grasslands, the presence of waters classified primarily in the class $\mathrm{Cl}-\mathrm{SO}_{4}-\mathrm{HCO}_{3}-\mathrm{Na}-\mathrm{Mg}$ (Fig. 2), with a significantly lower mineralization (conductivity), was

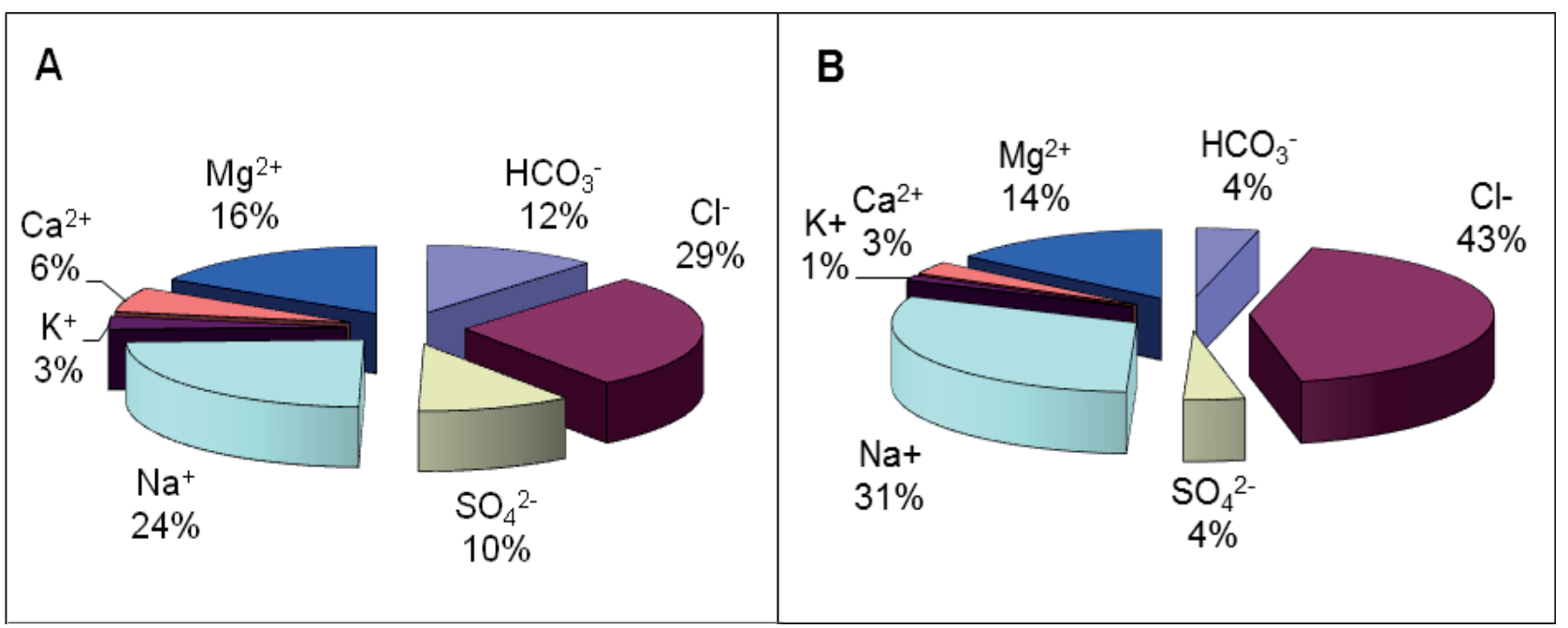

Figure 2. Average ionic composition of waters in low coast areas. A - relatively low water salinity, except for brackish seawater habitats $\left(\mathrm{EC}=542 \mu \mathrm{S} \cdot \mathrm{cm}^{-1} ; \mathrm{pH}=6.4 ; \mathrm{Cl}^{-}=119 \mathrm{mg} \cdot \mathrm{dm}^{-3}\right), \mathrm{B}-$ high mineralization and water salinity in areas occupied by salt grassland $\left(\mathrm{EC}=3170 \mathrm{~S} \cdot \mathrm{cm}^{-1} ; \mathrm{pH}=7.8 ; \mathrm{Cl}^{-}=916 \mathrm{mg} \cdot \mathrm{dm}^{-3}\right)$ 
observed. The dominance of chlorides and sodium in the composition of waters is no longer so distinct. Still, the share of chlorides as well as sulphates and magnesium are, here, kept above the concentration levels recorded in the hinterland and in the adjacent river waters (Staszek, 2007; Błaszkowska et al., 1996). It should be noted that hydrogencarbonate-calcium waters $\left(\mathrm{HCO}_{3}-\mathrm{Ca}\right)$ are the dominant hydrochemical class of inland waters in the area of Pomer- ania (Kostrzewski et al., 1993; Mazurek, 2000; Staszek, 2005, 2007).

The influence of the sea on the properties of water in maritime ecosystem is also shown in the very high and statistically significant $(\mathrm{r}=0.99, \mathrm{p}=0.01)$ correlation coefficient between chloride content and electrical conductivity (Table 1, Fig. 3), while the content of calcium ions is the main factor influencing the general mineraliza-

Table 1. Correlation matrix between the main properties of surface waters in the research area. Significant correlations at the level $\mathrm{p}=0.05$ were highlighted in bold

\begin{tabular}{|c|c|c|c|c|c|c|c|c|c|}
\hline & $\mathrm{pH}$ & $\mathrm{EC}$ & $\mathrm{SO}_{4}^{2-}$ & $\mathrm{Cl}^{-}$ & $\mathrm{HCO}_{3}^{-}$ & $\mathrm{Na}^{+}$ & $\mathrm{Ca}^{2+}$ & $\mathrm{Mg}^{2+}$ & $\mathrm{K}^{+}$ \\
\hline $\mathrm{pH}$ & 1.00 & & & & & & & & \\
\hline EC & 0.04 & 1.00 & & & & & & & \\
\hline $\mathrm{SO}_{4}^{2-}$ & 0.93 & 0.89 & 1.00 & & & & & & \\
\hline $\mathrm{Cl}^{-}$ & 0.80 & 0.99 & 0.87 & 1.00 & & & & & \\
\hline $\mathrm{HCO}_{3}^{-}$ & 0.71 & 0.91 & 0.82 & 0.91 & 1.00 & & & & \\
\hline $\mathrm{Na}^{+}$ & 0.84 & 0.99 & 0.84 & 1.00 & 0.90 & 1.00 & & & \\
\hline $\mathrm{Ca}^{2+}$ & 0.64 & 0.93 & 0.70 & 0.93 & 0.96 & 0.91 & 1.00 & & \\
\hline $\mathrm{Mg}^{2+}$ & 0.78 & 0.98 & 0.88 & 0.98 & 0.96 & 0.97 & 0.94 & 1.00 & \\
\hline $\mathrm{K}^{+}$ & 0.37 & 0.16 & 0.34 & 0.14 & -0.05 & 0.21 & -0.19 & -0.01 & 1.00 \\
\hline
\end{tabular}

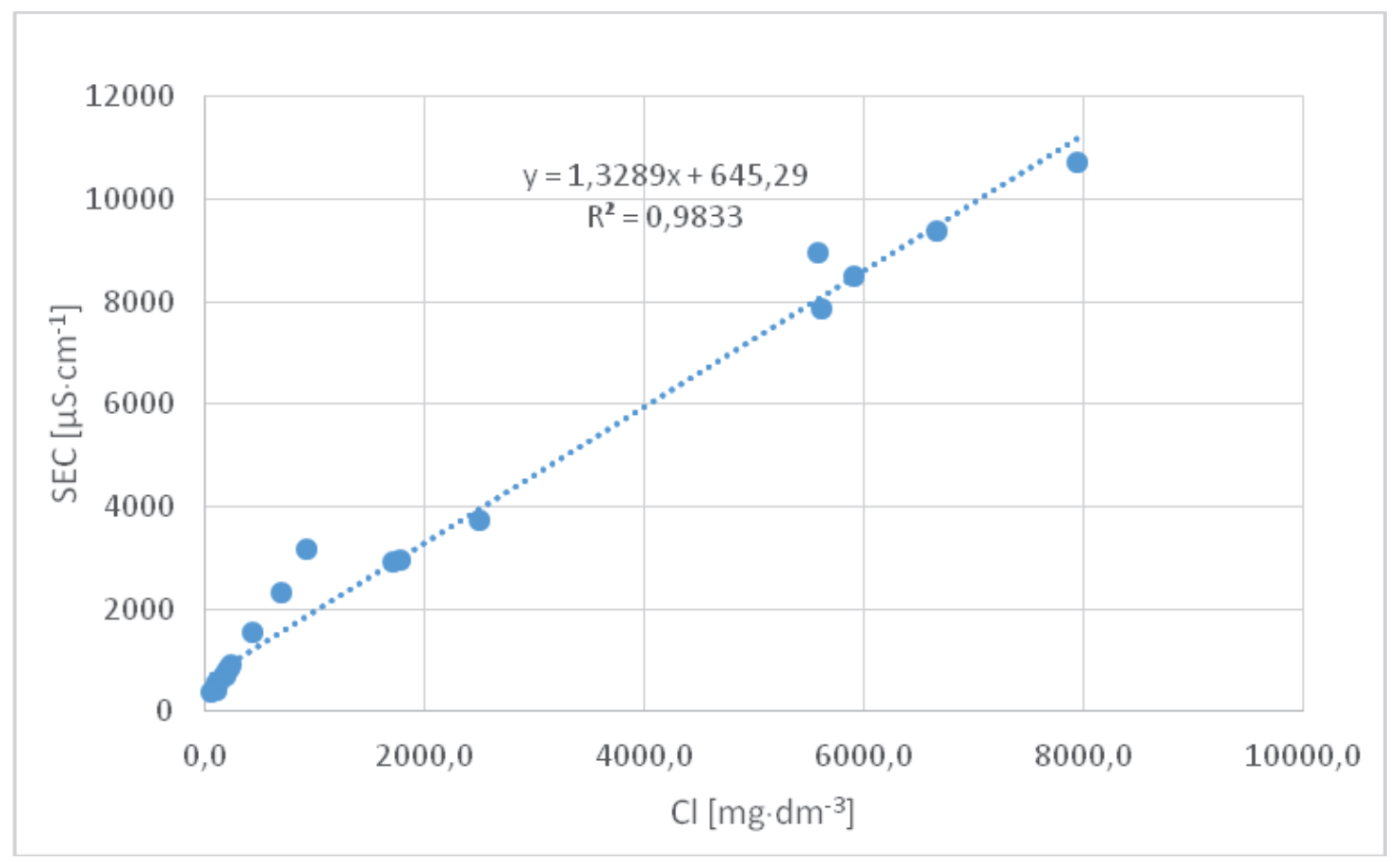

Figure 3. Relationship between chloride content and electrolytic conductivity of water in low coastal areas 
tion and conductivity of typical inland waters outside the coastal zone (Kostrzewski et al., 1993; Mazurek, 2000; Staszek, 2005, 2007). The importance of chlorides for the conductivity of typical inland waters in representative Pomeranian catchments is clearly lower, although statistically significant $(r=0.46 ; p=0.05)$ (Staszek, 2007). The relations of the share of basic minerals in the waters of low coast ecosystems are, therefore, clearly reversed in relation to inland waters, which can be considered as their characteristic feature. The very close dependence of electrical conductivity on the content of chlorides (Ta- ble 1, Fig. 3) is, therefore, an important diagnostic feature of the occurrence of water salination in the belt of low coast.

The analysis of basic water properties in the areas of salt grasslands and beyond shows significant differences in water mineralization (electrical conductivity) and chloride content (Fig. 4). The mean values of electrical conductivity of waters in the areas of brackish water within particular plots oscillated between $2054 \mu \mathrm{S} \cdot \mathrm{cm}^{-1}$ and $4720 \mu \mathrm{S} \cdot \mathrm{cm}^{-1}$ (Władysławowo - WŁ), and the extreme values within the range of $1191-8780 \mu \mathrm{S} \cdot \mathrm{cm}^{-1}$. Median EC
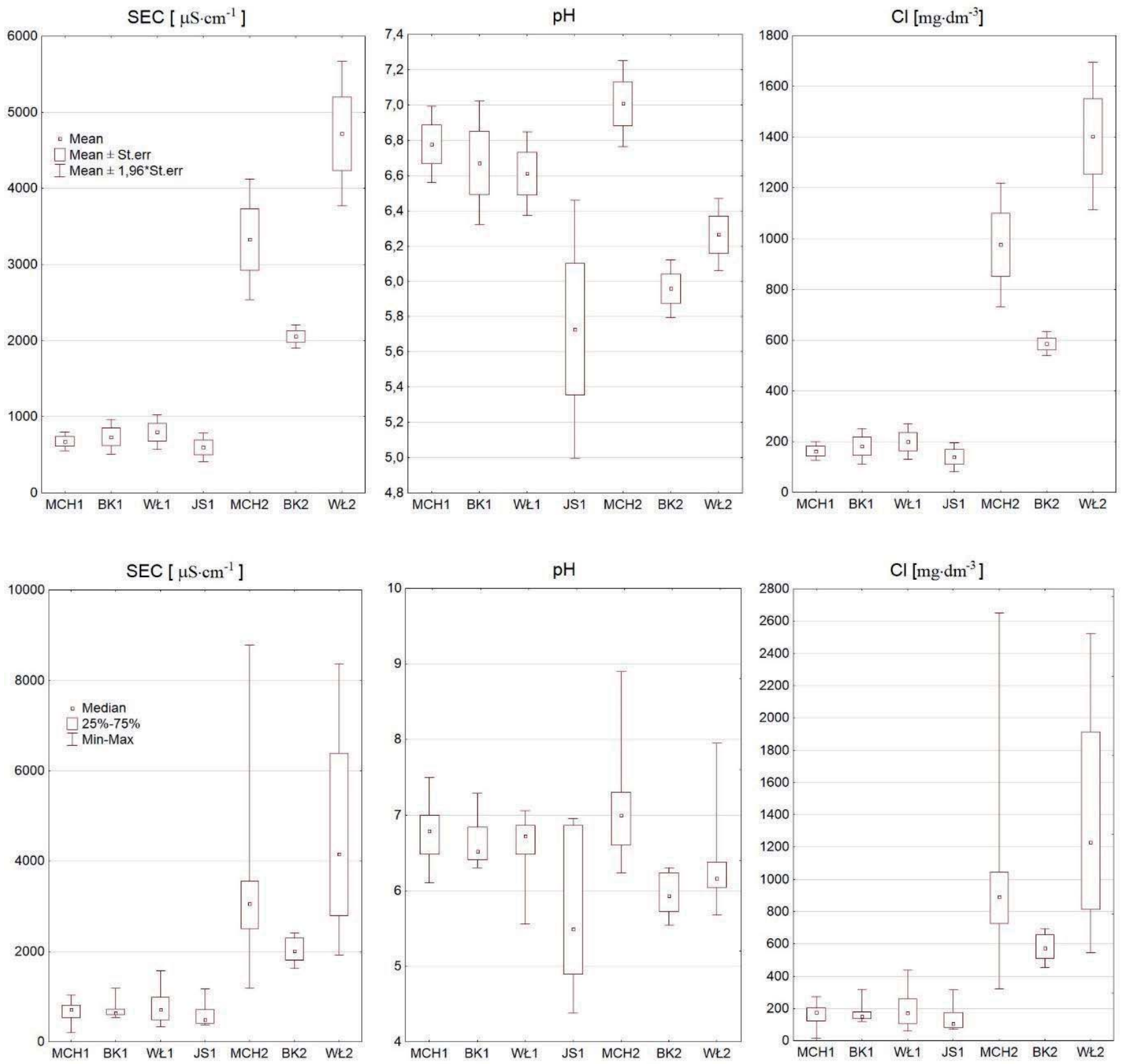

Figure 4. Comparison of main water properties in studied areas (marked as shown in Fig.1). Water of hydrogenic ecosystems without halophytes was additionally marked with number 1, saline ecosystems with halophytes with 2 
values were close to the mean, slightly lower than those $\left(2010-4150 \mu \mathrm{S} \cdot \mathrm{cm}^{-1}\right)$.

The average content of chlorides ranged, in particular plots, from $585,4 \mathrm{mg} \cdot \mathrm{dm}^{-3}($ Beka $-\mathrm{BK})$ to $1403,6 \mathrm{mg} \cdot \mathrm{dm}^{-3}$ (Władysławowo - WŁ). The values of both parameters show significant differences in relation to the waters of areas beyond the reach of halophyte vegetation. In coastal areas outside the salt grasslands, the SEC average values ranged from $599 \mu \mathrm{S} \cdot \mathrm{cm}^{-1}$ (Jastarnia - JS) to $797 \mu \mathrm{S} \cdot \mathrm{cm}^{-1}$ (Władysławowo - WŁ).

The current lack of saline communities on the surface of Jastarnia (JS) has also been confirmed by the results of the properties of the waters present here. The results show that presently, on this surface, the salinity is the weakest.

The results of the analyzes indicate a wide variation in $\mathrm{pH}$ of both brackish ecosystems and fresh waters occurring in other low coast areas, apart from the significant influence of hydrochemical impact of marine waters (Fig. 4). Within brackish water communities, the mean values of water $\mathrm{pH}$ ranged from 6.0 to 7.0, while finely at the border of $\mathrm{pH}$ value 5.5 to alkaline reaction of $\mathrm{pH}>8.0$.
There were no significant differences between the studied groups of waters of saline ecosystems and others.

\subsection{Main characteristics of the cliff ecosystems}

Representative sections, which best reflect the structure of habitats and ecosystems of cliff coasts that are formed under conditions of diverse marine abrasion, were presented on synthetic soil and habitat transects (Fig. 5). Transect A presents the structure of a typical section of active a cliff nearby Chłapowo. It is characterized by the occurrence of slopes with clearly marked landslide terrase (Subotowicz, 1982). The variable slope configuration greatly influences the intensity of denudation processes and, consequently, the differentiation of the soil cover and vegetation.

The cliff plateau (Fig. 5, profile A-1) does not undergo denudation processes associated with abrasion of the seacoast. In this area there is a Luvisol, characterized by lack of carbonates, practically, throughout the profile as well as acidic reaction $\left(\mathrm{pH}_{\mathrm{KCl}} 4.5\right.$ to 5.5$)$. Under such conditions, a community of Sarothamnus scoparius recognized as a community of Calluno-Sarothamnetum. In the case

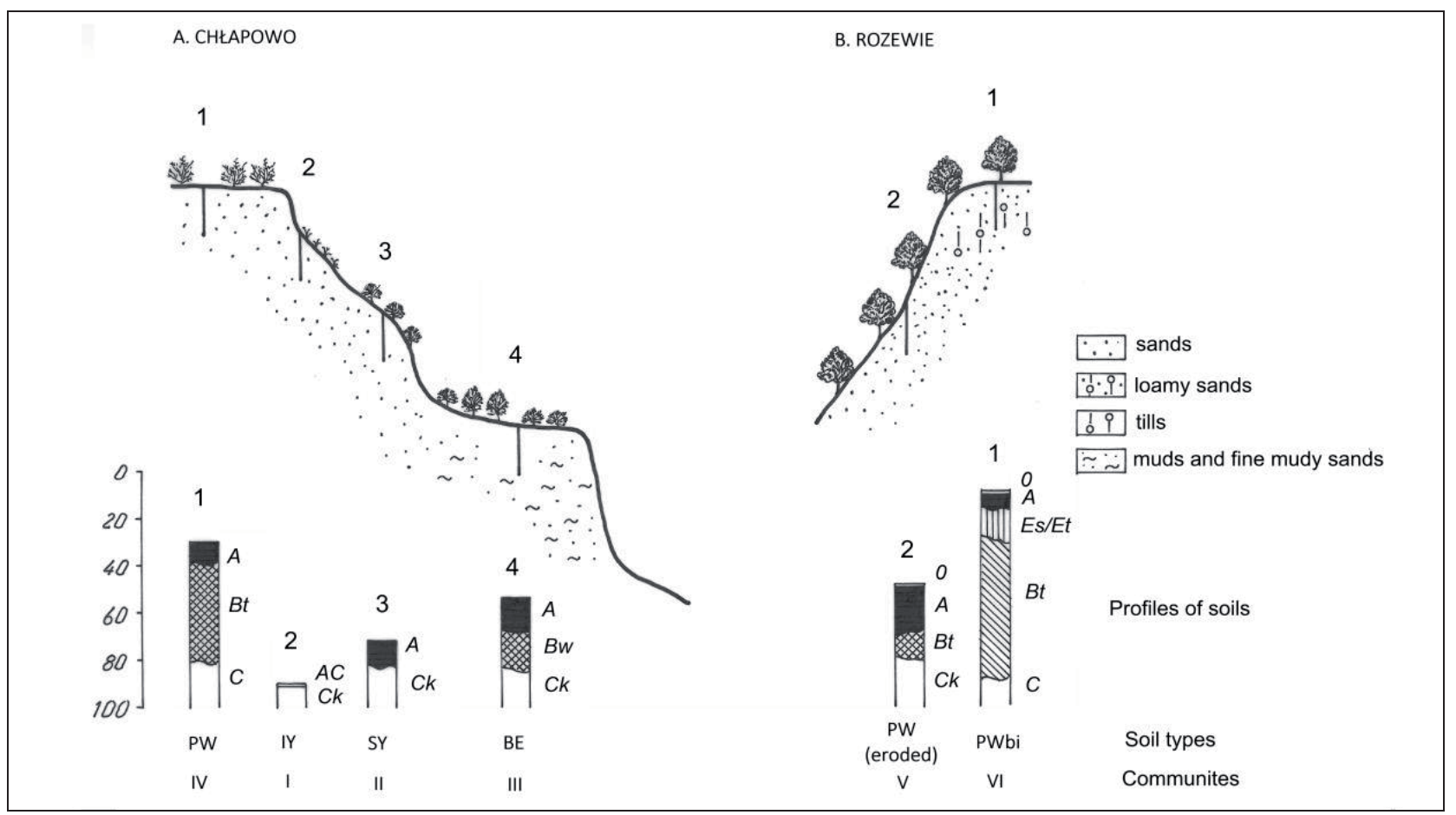

Figure 5. Soil and habitat transects of cliffs showing differentiation of soil types and ecosystems. Explanations:

Soil types at research sites: IY - Protic Regosol; SY - Regosol; BE - Eutric Cambisol; PW - Luvisol; PWbi - Albic Luvisols (Protospodic).

Vegetation: I - initial turf Trifolio-Anthylidetum maritimae, II - communities with sea buckthorn Hippophaëtum rhamnoides; III forest-shrub communities Salix caprea-Sorbus aucuparia; IV - Calluno-Sarothamnetum; V - Galio odorati-Fagetum; VI - Luzulo pilosae-Fagetum. 
of forest communities in analogous locations, with similar soil and habitat features, the occurrence of Luzulo pilosae - Fagetum (Orłowo - OR, Chłapowo-Rozewie, Jastrzębia Góra) was observed.

Within the upper slopes of the cliffs with high concentrations of slope processes (profiles A-2 and 3) there are Protic Regosols - AC-C profile. They are characterised by a diagnostic horizon (ochric) of negligible volume. The area is slightly covered by an initial grassy vegetation with Trifolio-Anthylidetum maritimae. On large surfaces there is loose sand without any vegetation cover. In the areas of locally flattened slopes there is Regosol, characterized by a distinctive ochric type of humus horizon with small thickness $(<10 \mathrm{~cm})$. Such surfaces are covered by a scrub community with sea-buckthorn Hippophaëtum rhamnoides. Developing on fresh sandy, as well as, sandy loam substrate, both initial and slighty formed soils exhibit a neutral reaction and contain calcium carbonate.

The cliff terrace zone (profile A-4) is characterized by the presence of features of longer, relative stabilization of the slope. This makes it possible to prolong the effects of pedogenesis. This results in a much clearer formation of humus horizon (ochric) as well as the presence of the cambic horizon. In this site there is Eutric Cambisol (young stage of forming) with the O-A-Bw$\mathrm{Ck}$ profile. At the same time, it shows high humidity and a reaction close to neutral. Under such conditions, a shrubby formation with goat willow and rowanberry Salix caprea-Sorbus aucuparia was formed with sea buckthorn, wild elderberry and cherry tree. The species composition of the fleece, in which the plants with high ecological requirements, including nitrophytes, are noted, also highlights the eutrophic and quite damp character of the habitat.
In the study section of Jastrzębia Góra (JSG), in the analogous position (terrace of the cliff edge), Eutric Gleyic Cambisols were observed, and also sporadically Phaeozems (Colluvic) (Fig. 6). In the case of the latter, significant concentrations of slope processes are manifested by the presence of buried and accumulation horizons. These soils are characterized by the O-A-Ckn-Ab-2Ckg structure. They are formed locally in moist landslide niches, on groundwater exudates. In such situations, the presence of a humus horizon, similar to that of the mollic, was recorded in the upper part of the profile. Its thickness is often more than $20 \mathrm{~cm}$ in the case of gleyic cambisols and in the case of colluvial soils $50-60 \mathrm{~cm}$. These soils are the main habitat of low sycamore forests Sorbus aucuparia-Acer pseudoplatanus (Chojnacki, 1979; Markowski, 1998), whereas, as a result of additional groundwater inflow, forms referring to riverine forest (not considered in taxonomy) with the physiognomy of low-alder forest (Chojnacki, 1979). The above mentioned sequence of soil types and associated community types can be considered as a typical pattern of spatial diversity of active cliff ecosystems in the studied area.

The studies carried out on the remaining cliffs (Kolibki - KB, Orłowo - OR) confirm the connection of shortterm stable slopes with formation of slighty formed shallow Luvisols with Hippophaëtum rhamnoides and Calluno-Sarothamnetum communities. In the latter case, acidification of the upper soil profile ( $\mathrm{pH} 4.5-5.5)$ seems to be an important factor determining the occurrence of the syndrome.

A typical toposecction of dead cliff ecosystems is presented in the example of Rozewie (Fig. 5 - transect B). This part of the coastline, which was originally very active, was artificially, strengthened and stabilized in 1908 (Subotowicz, 1982).

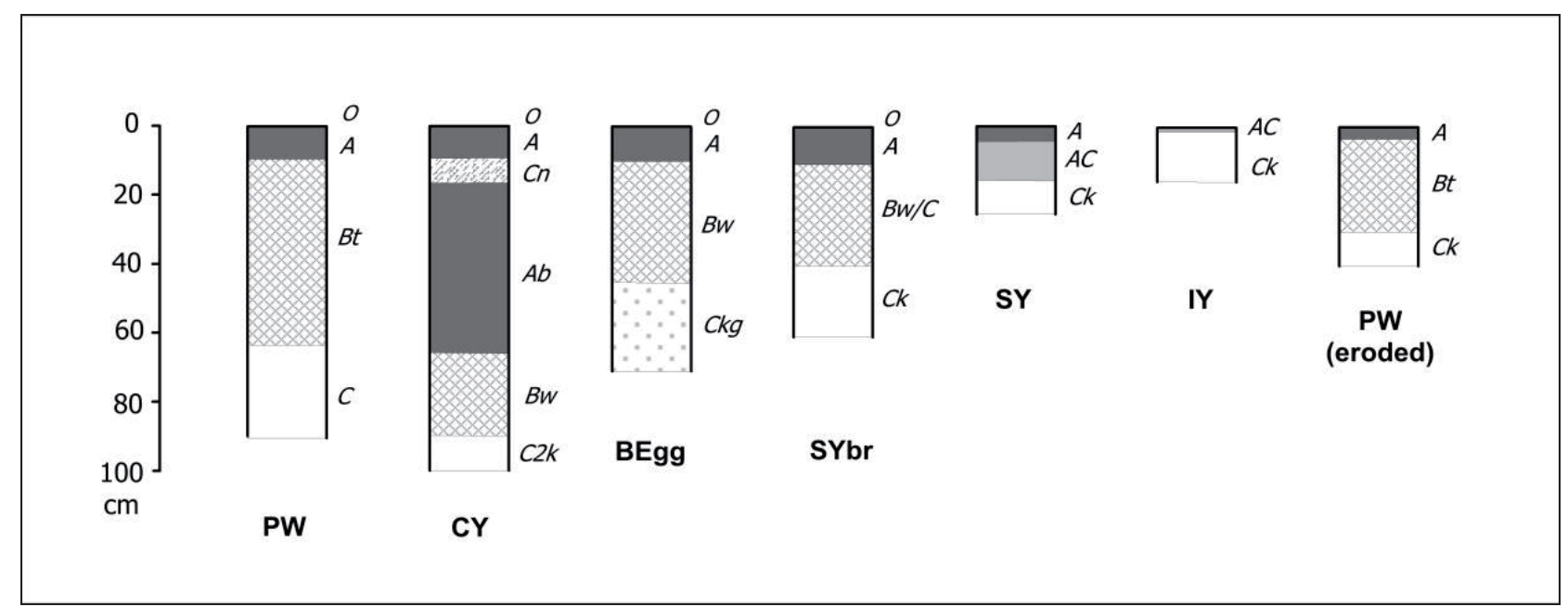

Figure 6. Selected soil profiles characteristic for the studied cliffs. Symbols of soil types: CY - Phaeozems (Colluvic), BEgg - Eutric Gleyic Cambisol, SYbr - Cambic Regosol. Other symbols as shown in Figure 5 
Table 2. Main characteristics of the cliff ecosystems

\begin{tabular}{|c|c|c|c|}
\hline Cliff & $\begin{array}{l}\text { Terrain features } \\
\text { and their dynamics }\end{array}$ & Types of soil* and habitat characteristics & Typical plant communities \\
\hline \multirow{8}{*}{ 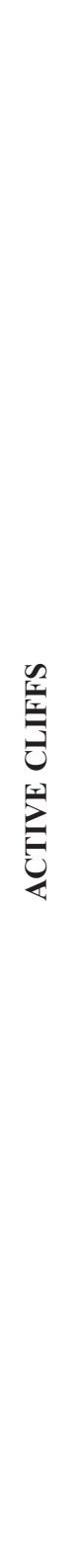 } & $\begin{array}{l}\text { Cliff plateau } \\
\text { Small slopes, no } \\
\text { clear or obvious signs } \\
\text { of denudation }\end{array}$ & $\begin{array}{l}\text { PW/PWbi - Luviols/Albic Luvisols } \\
\text { (Protospodic) } \\
\text { Deep leaching of calcium carbonate and acidic } \\
\text { reaction ( } \mathrm{pH} 4.5-5.5 \text { ) in the whole profile. }\end{array}$ & $\begin{array}{l}\text { Poor beech forest Luzulo pilosae - Fagetum. } \\
\text { In the section of Jastrzębia Góra there } \\
\text { are often communities with Calluno- } \\
\text { Sarothamnetum. }\end{array}$ \\
\hline & \multirow{4}{*}{$\begin{array}{l}\text { Cliff slopes } \\
\text { Strongly denuded } \\
\text { steep slopes }\left(30-60^{\circ}\right) \\
\text { undergoing permanent } \\
\text { or seasonal abrasion }\end{array}$} & $\begin{array}{l}\text { IY - Protic Regosols; } \\
\text { Clay soils, rich in calcium, neutral reaction } \\
(\mathrm{pH} \geq 7)\end{array}$ & $\begin{array}{l}\text { Innitial community Poo-Tussilaginetum } \\
\text { farfarae. }\end{array}$ \\
\hline & & $\begin{array}{l}\text { IY - Protic Regosols; } \\
\text { Sandy soils, rich in calcium, neutral reaction } \\
(\mathrm{pH} \geq 7)\end{array}$ & $\begin{array}{l}\text { Grassland with Anthyllis vulneraria and } \\
\text { Lathyrus pratensis Trifolio-Anthylidetum } \\
\text { maritimae. }\end{array}$ \\
\hline & & $\begin{array}{l}\text { SY - Regosols, with diagnostic thin ochric } \\
\text { horizon } \\
\text { Sandy or clay soils rich in calcium, neutral } \\
\text { reaction or slightly acidic at the surface (pH 6-7). }\end{array}$ & $\begin{array}{l}\text { Shrubby formations, sea buckthorn } \\
\text { Hippophaëtum rhamnoides, in places } \\
\text { with goat willow, silver birch, scots pine, } \\
\text { numerous species of shrubs. }\end{array}$ \\
\hline & & $\begin{array}{l}\text { PW - eroded Luvisols with shallow, slighty } \\
\text { formed profile (to } 50 \mathrm{~cm} \text { ), thickness of the } \\
\text { ochric epipedon up to } 5-10 \mathrm{~cm} \text {; acidification } \\
\text { in the upper soil horizons (pH 5.5-6.5). }\end{array}$ & $\begin{array}{l}\text { Communities with common broom Hollco } \\
\text { mollis - Cytisetum scoparii (Markowski, } \\
\text { 1998). In places, varied share of other } \\
\text { shrubs and trees - silver birch, Scots pine. }\end{array}$ \\
\hline & \multirow[t]{2}{*}{$\begin{array}{l}\text { Terraces on cliff } \\
\text { slopes; accumulation } \\
\text { of denuded material } \\
\text { from the upper parts } \\
\text { of slopes }\end{array}$} & $\begin{array}{l}\text { SY(br)** - Cambic Regosols with a slighty } \\
\text { formed cambic horizon, thickness of the ochric } \\
\text { epipedon up to } 10 \mathrm{~cm} \text {, slightly acidic at the } \\
\text { surface (pH 5.5-6.5). }\end{array}$ & $\begin{array}{l}\text { Communities of hazel and rowan Corylus } \\
\text { avellana-Sorbus aucuparia; } \\
\text { Community of goat willow and rowan- } \\
\text { Salix caprea-Sorbus aucuparia. }\end{array}$ \\
\hline & & $\begin{array}{l}\text { BE - Eutric Cambisols - humus horizon with } \\
\text { mollic characteristics } 20-40 \mathrm{~cm} \text { of thickness } \\
\text { Non-leached soils, calcareous, with neutral } \\
\text { reaction ( } \mathrm{pH} \text { ok. } 6.5-7 \text { ). }\end{array}$ & $\begin{array}{l}\text { Community of rowan and sycamore Sorbus } \\
\text { aucuparia-Acer pseudoplatanus. }\end{array}$ \\
\hline & $\begin{array}{l}\text { Same as above - } \\
\text { on groundwater } \\
\text { exudations }\end{array}$ & $\begin{array}{l}\text { BE/BEgg - Eutric Cambisols/ Eutric Gleyic } \\
\text { Cambisols; } \\
\text { Locally: } \\
\text { CY - Phaeozems (Colluvic) with well-developed } \\
\text { mollic-like horizon ( } 40-60 \mathrm{~cm} \text { of thickness). } \\
\text { Neutral reaction (pH } 6.5-7 \text { ) and content } \\
\text { of calcium supplied by groundwaters with high } \\
\text { mineralization and alkaline reaction (SEC 631- } \\
\left.837 \mu \mathrm{S} \cdot \mathrm{cm}^{-1}, \mathrm{pH} 7.0-7.5\right) \text {. }\end{array}$ & $\begin{array}{l}\text { Community of rowan and sycamore Sorbus } \\
\text { aucuparia-Acer pseudoplatanus; } \\
\text { Community of rowan and sycamore Sorbus } \\
\text { aucuparia-Acer pseudoplatanus } \\
\text { - form referring to riparian forest } \\
\text { (Chojnacki, 1979) with black alder (rich, } \\
\text { eutrophic, humid alder forest). }\end{array}$ \\
\hline \multirow{2}{*}{ 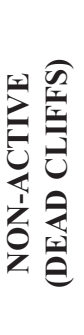 } & $\begin{array}{l}\text { Cliff plateau. } \\
\text { Small slopes, } \\
\text { no obvious signs } \\
\text { of denudation }\end{array}$ & $\begin{array}{l}\text { PW/PWbi - Luviols/Albic Luvisols } \\
\text { (Protospodic) } \\
\text { Deep leaching of calcium carbonate and acidic } \\
\text { reaction (pH 4.5-5.5) in the whole profile. }\end{array}$ & Poor beech forest Luzulo pilosae - Fagetum. \\
\hline & $\begin{array}{l}\text { Stabilized steep slopes } \\
\left(30-50^{\circ}\right) \text { with relatively } \\
\text { small denudation (no } \\
\text { landslides) }\end{array}$ & $\begin{array}{l}\text { PW - Luvisols (eroded) } \\
\text { Acidic at the surface layers ( } \mathrm{pH} 4.5-6.5) \text { and } \\
\text { leached of } \mathrm{CaCO}_{3 .} \text { Presence of carbonates in the } \\
\text { bedrock. }\end{array}$ & Rich beech forest Galio odorati - Fagetum. \\
\hline
\end{tabular}

* - acronyms of soil types according to: Polish Soil Classification (2011), English equivalent names after Kabała et al. (2016).

** - subtype not distinguished in Polish Soil Classification (2011). 
The morphologically stable zone of dead cliff tops (Fig. 5, Profile B-1) is characterised by a Luvisols (sometimes Albic Luvisols).

In similar terrain locations in other sections (Kolibki KB, Orłowo - OR, Jastrzębia Góra - JSG) the occurrence of Luvisols was also observed. Regardless of the soil types and subtypes, they are characterised by leaching out calcium carbonate and acidic (4.5-5.5) in the whole soil profile. A typical plant complex with the character of a permanent klimax community is the acidic beech forest Luzulo pilosae-Fagetum.

The steep slope with slopes exceeding $45^{\circ}$ (profile B-2) is overgrown by the Galio odorati-Fagetum. Despite the steep slopes, there is no evidence of mass movements and intense rejuvenation. A shallow eroded Luvisols with upper horizons of acidification (A and $\mathrm{Bt}$ ) developed here, in the presence of calcium carbonate and neutral in the parent rock $(\mathrm{Ck})$. The analogous characteristics of soils and communities on the stabilized slopes of the dead cliffs were also found on other surveyed areas (Orłowo - OR, Jastrzębia Góra - JSG).

A synthesis of the main features of cliff ecosystems on the analysed sections is presented in Table 2.

Groundwaters forming effluents and outflows on the examined sections of cliffs are characterised by relatively high mineralization (electrolytic conductivity) and neutral or poorly alkaline reaction (Table 3 ). Their conductivity is higher than that of average groundwater in the postglacial morainic plateaus (Mazurek, 2008; Mazurek et al., 2015; Pruszkowska, 1999; Staszek 2005).

Although the lack of analysis of the ionic composition makes it impossible to describe these waters in a broader way, it is beyond doubt that as waters rich in mineral substances, including calcium and magnesium cations, they are a significant modifier of local habitat conditions, affecting the development of humid soils of eutrophic character.

\section{Discussion}

Studies have shown that the surveyed coastal brackish ecosystems on the shores of the Bay of Puck develop under conditions of waters with EC values above $2000 \mu \mathrm{S} \cdot \mathrm{cm}^{-1}$ and chloride content above $600 \mathrm{mg} \cdot \mathrm{dm}^{-3}$. The issue of unequivocal acceptance of these limit values is a difficult issue due to the following factors:
- the strong seasonal variability of water levels and their properties (Cieśliński, 2007; Hulisz, 2013; Jokiel, 2016), however, the high dynamics of water properties changes concerns in particular drainage channels and ditches with direct connection to the sea (Cieśliński, 2007; Jokiel, 2016);

- Research in the zone of mixing within a small area of inflows of inland, marine and rain waters, where the borders between zones of clear differences in water properties are temporary.

The results obtained and their interpretation, however, support the adoption of given values as a lower threshold of environmental conditions, which determine the possibility of developing coastal ecosystems of salt grasslands. These values are comparable to the results obtained by other authors. The results of the R. Cieśliński (2007) study indicate that average concentrations of chlorides in surface waters in saltwater areas range from 500 to over $2500 \mathrm{mg} \cdot \mathrm{dm}^{-3}$. According to data of A. Jokiel (2012) the values of electrical conductivity of surface waters in the Władysławowo area of halophilic vegetation, regardless of the research period, were similar and varied from 1523 to $7870 \mu \mathrm{S} \cdot \mathrm{cm}^{-1}$ (4426). Hulisz (2013) shows the presence of brackish marshes on the Polish coast with water conductivity in the range of $3380-3550 \mu \mathrm{S} \cdot \mathrm{cm}^{-1}$ and $590-980$ $\mathrm{mg} \cdot \mathrm{dm}^{-3}$ chloride content, with these results referring to soil and ground waters, where the degree of mineralisation is higher than surface waters.

It should be taken into account that the occurence of salinity of water and soils is not consistence with the presence of brackish water on the coast, as the proper meadowpasture use is an extremely important factor determining their formation (Herbich, 2004; Sąin, 1999). Nevertheless, the water properties described in this paper are an important element in the assessment of habitat potential for the development of salt grassland ecosystems. They can therefore be used as an indicator of the potential of these ecosystems' habitats.

At the same time, the existence of brackish coastal ecosystems is associated with a wide variation in water $\mathrm{pH}$, which for the upper and lower percentile (10-90\%) are at $\mathrm{pH} 5.6$ - 7.4. This is due to the overlap of the interaction of different environments of composition and water properties. The salt grasslands are affected by both alkaline sea waters in the Baltic Sea coastline at $\mathrm{pH}$ levels 7.4-8.6 (Hulisz, 2013) and inland river and groundwater - usu-

Table 3. The $\mathrm{pH}$ and electrical conductivity of groundwater on the tested three sections of cliff banks

\begin{tabular}{|c|c|c|c|}
\hline Properties & Kolibki (KB) & Orlowo (OR) & Jastrzębia Góra (JSG) \\
\hline $\mathrm{pH}$ & $6.89-7.23$ & $7.56-7.75$ & $7.00-7.55$ \\
$\mathrm{EC}\left[\mu \mathrm{S} \cdot \mathrm{cm}^{-1}\right]$ & $750-928$ & $1095-1378$ & $631-837$ \\
\hline
\end{tabular}


ally characterised by a slightly acidic or neutral reaction (Błaszkowska et al., 1996; Staszek, 2005, 2007). The direct inflow and stagnation of acid rainwater on poorly permeable peat bogs has the important role in the acidification of the waters of the studied ecosystems. However, the occurrence of potential acid sulphate soils is probably the decisive factor here (Hulisz, 2013). The processes of sulphide oxidation and strong acidification of these soils are manifested in the occurrence of lower $\mathrm{pH}$ values of waters of saltwater ecosystems, whose extreme values reached $\mathrm{pH}$ 5.5 (Beka). This is yet another effect of the impact of material transformation processes related to the impact of the sea.

The spatial extent of the sea's impact on the specific habitats of halophytes depends at least on several important factors, such as:

- the shape of the surface of the coast, the presence or absence of morphological barriers (shore embankment, dune embankment);

- the presence of natural or anthropogenic routes of seawater intrusion into the land area (waste watercourses, canals, drainage ditches);

- Intensity of allochthonous inflows of inland waters and groundwater, determined by unit outflows, hydraulic gradients and soil filtration parameters.

It was also reported that the zone near to the seashore line is enriched with allochthonous organic matter (Hulisz et al., 2012).

The results of the conducted research indicate that suitable habitat conditions for halophyte ecosystems, conditioned by the influence of the sea, are maintained at a distance from approx. 100-250 m (Władysławowo) to over $600 \mathrm{~m}$ (Beka). According to the results of other authors' research, in the case of larger channels connected with the sea, high values of salinity and mineralisation may persist even at a distance of up to $1 \mathrm{~km}$ from the shore (Cieśliński, 2007; Jokiel, 2016). At the same time, on practically each of the surveyed areas, there are clearly visible zones of inflow of fresh water inflows, which sometimes influence the significant narrowing of the area of brackish water occurrence and thus the conditions suitable for the presence of salt grasslands (Cieśliński, 2007; Jokiel, 2012).

It should be clearly stated that the distances mentioned above refer to parts of the coastline, which are not connected with the occurrence of flooding or estuaries of large rivers. In the case of large coastal floodplains and estuary stretches of rivers, the opportunities for marine waters to penetrate inland and create habitats conducive to halophytes are much greater. In Pomerania, such conditions are known from the northern part of the Szczeciński Lagoon (reverse delta of the Świna river) and Kamieńskie Lakes, where the documented salinity of waters and presence of halophytes is recorded at distances of up to $5 \mathrm{~km}$ from the sea shore (Czyż et al., 2010; Hulisz, 2013; Sagin, 1999).
On the other hand, the intensity of abrasion processes and associated denudation is a major factor influencing the diversity of active coastal cliff ecosystems. Their individual specificity is determined mainly by the very large diversity of soils and habitats resulting from the variable dynamics of abrasion and denaturation processes, different configuration of slopes, lithological differences of the ground rocks, as well as resulting from the different age and degree of soil cover development.

Intensive slope processes are responsible for the development of coastal-specific Protic Regosols and Arenosols as well as other types of soil, including colluvial soils. Morphodynamic activity is also a factor inhibiting the processes of washing the soils and leaching mineral substances, mainly calcium carbonate. The common calcium carbonate content and high reaction values are specific to the soils on the slopes of the active cliffs. This feature distinguishes the ecosystems of cliff shores from other ecosystems commonly found in the Pomeranian region, where deep carbonate leaching and soil acidification (Herbich, 1994) predominate, typical for soils developing in the climatic conditions of the Polish area (Kowalkowski, 1988; Konecka-Betley et al., 1995).

On the other hand the occurrence of Luvisols and its eroded forms along the morphologically more stable parts of dead cliffs can be compared to the result of pedological researches which recently been reported in the other studies provided in the young morainic zone of Poland (Świtoniak, 2016).

Within the terraces and flattening of cliff slopes, processes of denaturation of both mineral matter and organic parts take place, which in favourable conditions leads to intensive accumulation of humus and formation of characteristic colluvial soils (propably also with the diagnostic mollic horizon). In such conditions, there are eutrophic communities of low-grade sapwood forests, and in the most humid forms of groundwater beds, phytocenoses referring to the ridges.

The influence of groundwater bays on the formation of specific ecosystems on cliffs is strongly dependent on the configuration of slopes and the existence of well-developed landslide niches. Among the examined sections, only very small fragments of the cliff in Jastrzębia Góra (JSG) had the conditions for full development of soil and habitat conditions typical for the area of groundwater effluents and associated low-grade alder forests.

\section{References}

Bednarek R. 1979. Gleby wybranych odcinków klifowych polskiego wybrzeża Bałtyku [Soils of the selected sections of Polish Baltic seashore]. Studia Soc. Sc. Toruń. Sec. D. 10: 6: 1-124. 
Błaszkowska B., Gerstmanowa E. \& Narwojsz A., 1996, Monografia rezerwatu przyrody „Beka”. Środowisko fizycznogeograficzne [The „Beka” nature reserve Monography. Physico-geographical environment], [in:] M. Przewoźniak (ed.), Materiały do monografii przyrodniczej regionu gdańskiego, T.1 [Material collected for the monograph on nature of the Gdańsk region, Vol. 1]. Wyd. Gdańskie, Gdańsk: 88-99.

Chojnacki W., 1979, Roślinność zboczy klifowych Pobrzeża Kaszubskiego [Vegetation of the cliff sea shores of the Kashubian Coast]. Soc. Sc. Gedan., Acta Biologica 4: 5-40.

Cieśliński R., 2007, Chemizm wód [Chemistry of waters], [in:] J. Fac-Beneda, R. Cieśliński (eds), Wody słonawych podmokłości delty Redy i Zagórskiej Strugi, GTN Gdańsk: 93-106.

Czyż H., Kitczak T. \& Durkowski T., 2010, Charakterystyka zbiorowisk roślinnych z udziałem słonorośli oraz ich ochrona na obszarze wstecznej delty Świny [Characteristic of the communities with halophytes and its protecion in the delta of Świna river], Rocznik Ochrona Środowiska, T.10, Środkowo-Pomorskie Towarzystwo Naukowe Ochrony Środowiska, Koszalin: 109-125.

Herbich J., 1994, Przestrzenno-dynamiczne zróżnicowanie roślinności dolin w krajobrazie młodoglacjalnym na przykładzie Pojezierza Kaszubskiego [Spatial and dynamic diversity of valleys vegetation in the young-glacial landscape on the example of the Kashubian Lake District]. Monographiae Botanicae, vol. 76/1, Łódź: $1-174$.

Herbich J., 2004, Solniska nadmorskie (Glauco-Puccinellietalia, część - zbiorowiska nadmorskie) [Salt marhes (Glauco-Puccinellietalia, Part - seashore communities)], [in:] J. Herbich (ed.), Poradnik ochrony siedlisk i gatunków Natura 2000 - podręcznik metodyczny, Ministerstwo Środowiska, Warszawa: 86-96.

Hulisz P., Krześlak I. \& Karasiewicz T., 2012, Characteristics of sedimentary environments in brackish marsh soils in relation to organic matter properties (Puck Lagoon, Northern Poland). Ecological Questions 16: 8797.

Hulisz P., 2013, Geneza, właściwości i pozycja systematyczna marszy brakicznych w strefie oddziaływania wód Bałtyku [Genesis, properties and systematics position of the brackich marsh soils in the Baltic coastal zone]. Wyd. Naukowe UMK, Toruń: 1-138.

Hulisz P., Piernik A., Mantilla-Contreras J. \& Elvisto T., 2016, Main Driving Factors for Seacoast Vegetation in the Southern and Eastern Baltic. Wetlands 36: 909919.

Jokiel A., 2012, Sprawozdanie końcowe z projektu pt. „Krótkoterminowa zmienność sytuacji hydrologicznej na obszarze rezerwatu Słone Łąki" [Final report from the project "Short-term variability of the hydrological conditions in the area of the Słone Ląki nature reserve"'], mnscr., UG, Gdańsk: 1-19.

Jokiel A., 2016, Analiza danych hydrologicznych zebranych w rezerwacie przyrody „Beka” w okresie od 01.11.2012 r. do 31.10.2016 r. [Analysis of hydrological data collected within the „Beka” nature reserve during the period 01.11.2012 r. do 31.10.2016]. Opracowanie wykonane $\mathrm{w}$ ramach realizacji projektu pt. „Zrównoważona turystyka i ekstensywne rolnictwo dla rezerwatu przyrody Beka”. Fundacja Rozwoju UG, Gdańsk: 1-85.

Kabała C., Świtoniak M. \& Charzyński P., 2016, Correlation between the Polish Soil Classification (2011) and international soil classification system World Reference Base for Soil Resources (2015). Soil Science Annual 67 (2): 88-100.

Kondracki J., 1994, Geografia Polski. Mezoregiony fizyczno-geograficzne [Geography of Poland. Physicogeographical mezoregions]. PWN, Warszawa: 1-339.

Konecka-Betley K., Kuźnicki F. \& Zawadzki S., 1995, Systematyka i charakterystyka gleb Polski [Polish soil classification and characteristic], [in:] B. Dobrzański, S. Zawadzki (eds), Gleboznawstwo. PWRiL, Warszawa: 330-479.

Kowalkowski A., 1988, Ewolucja gleb w holocenie [The evolution of the soils in Holocene period], [in:] L. Starkel (ed.), Geografia Polski. Środowisko przyrodnicze. Ossolineum, Wrocław: 127-136.

Kostrzewski A., Mazurek M. \& Zwoliński Z., 1993, Sezonowa zmienność składu chemicznego wód górnej Parsęty (Pomorze Zachodnie) jako odzwierciedlenie funkcjonowania systemu zlewni [Seasonal variablity of chemical composition of upper Parsęta waters (Western Pomerania) as the result of the catchment's system functioning], [in:] A. Kostrzewski (ed.), Geoekosystem obszarów nizinnych. Zeszyty Naukowe „Człowiek i Środowisko”, 6, Komitet Naukowy przy Prezydium PAN, Warszawa: 79-99.

Markowski R., 1998, Roślinność brzegu klifowego między Cetniewem a Jastrzębią Górą [Vegetation of cliff seashore between Cetniewo and Jastrzębia Góra], [in:] Szata roślinna Pomorza - zróżnicowanie, dynamika, zagrożenia, ochrona. Przewodnik sesji terenowych 51 Zjazdu Polskiego Towarzystwa Botanicznego. Wyd. UG, Gdańsk: 111-116.

Markowski R., Fałtynowicz W. \& Sągin P., 1998, Rezerwat im. prof. Z. Czubińskiego. Nadmorski klif woliński i jego roślinność [The nature reserve of prof. Z. Czubiński. Wolin cliff seashore and its vegetation], [in:] Szata roślinna Pomorza - zróżnicowanie, dynamika, zagrożenia, ochrona. Przewodnik sesji terenowych 51 Zjazdu Polskiego Towarzystwa Botanicznego. Wyd. UG, Gdańsk: 37-40.

Mazurek M., 2000, Zmienność transportu materiału rozpuszczonego w zlewni Kłudy jako przejaw 
współczesnych procesów denudacji chemicznej (Pomorze Zachodnie) [Variability of dissolved material transport in the Kłuda catchment as an effect of chemical denudation processes (Western Pomerania)]. Wyd. Nauk. UAM, Poznań: 1-124.

Mazurek M., 2008, Czynniki kształtujące skład chemiczny wypływów wód podziemnych w południowej części dorzecza Parsęty (Pomorze Zachodnie) [The factors of groundwaters chemical composition in springs of the south part of Parsęta catchment (Western Pomerania)]. Przegląd Geologiczny 56(2): 131-139.

Mazurek M., Kruszyk R. \& Szpikowska G., 2015, Role of channel heads in determining water chemistry of 1storder streams in postglacial areas of West Pomerania. Prace Geograficzne 143, IGiGP UJ, Kraków: 47-64.

Meissner W., Markowski R., Żółkoś K. \& Janta A., 1999, Przyroda okolic Jastarni. Przewodnik merytoryczny po ścieżce dydaktycznej [Nature of the Jastarnia area. Guidebook of the educational path], [in:] A. Janta (ed.), Torfowe Kłyle. Ścieżka przyrodnicza po okolicach Jastarni. Wyd. Nadmorski Park Krajobrazowy, Władysławowo: 6-16.

Pazdro Z., Kozerski B., 1990, Hydrogeologia ogólna [Basic hydrogeology]. Wyd. Geol. Warszawa: 1-623.

Piernik A. \& Hulisz P., 2011, Soil-plant Relation in Inland Natural and Antropogenic Saline Habitats. The European Journal of Plant Science and Biotechnology, Global Science Books: 37-43.

Piotrowska H. 1993. Buczyna storczykowa wzdłuż nadmorskiego klifu na wyspie Wolin [Beech orchid forest along the coastal cliff of Wolin island]. Zesz. Nauk UG., Biologia 10: 5-29.

Piotrowska H., 2003, Zróżnicowanie i dynamika nadmorskich lasów i zarośli [Diversity and dynamics of coastal forests and thickets]. Bogucki Wyd. Naukowe, Poznań: 1-102.

Pruszkowska M., 1999, Tło i anomalie hydrogeochemiczne wód podziemnych z utworów czwartorzędowych Pojezierza Kaszubskiego [Range and anomalies of the groundwater hydrogeochemical properties from Quaternary deposits within the Kashubian Lake District].
Wydz. Inż. Środ. Politechniki Gdańskiej, Gdańsk: $1-104$.

Przewoźniak M., 1991, Krajobrazowy system interakcyjny strefy nadmorskiej w Polsce [The landscape interaction system of the coastal zone in Poland]. Rozprawy i monografie UG. 172, Wyd. UG, Gdańsk: 1-150.

Sągin P., 1999, Cenne składniki szaty roślinnej Karsiborskiej Kępy (wsteczna delta Świny) i problemy ich ochrony [Valuable components of Karsiborska Kępa vegetation (delta of Świna river) and the problems of their protection]. Folia Universitatis Agriculturae Stetinensis 197, Agricultura 75: 283-286.

Staszek W., 2005, Struktura funkcjonalna geosystemu młodoglacjalnego na przykładzie dorzecza Borucinki [Functional structure of young-glacial geosystem on an example of Borucinka catchment]. Prace i Studia Geograficzne, T. 36, UW, Warszawa: 79-88.

Staszek W., 2007, Zmienność krajobrazów roślinnych siedlisk wilgotnych i bagiennych jako efekt zróżnicowania warunków hydrochemicznych w zlewni młodoglacjalnej [Diversity of the vegetation landscapes of moist and bog habitats as the effect of different hydrochemical conditions in young-glacial watershed], [in:] K. Ostaszewska, I. Szumacher, S. Kulczyk, E. Malinowska (eds), Znaczenie badań krajobrazowych dla zrównoważonego rozwoju. Wyd. UW, Warszawa: 439-450.

Subotowicz W., 1982, Litodynamika brzegów klifowych wybrzeża Polski [Lithodynamic of the Polish cliff seashores]. Ossolinuem, Wrocław: 1-151.

Systematyka gleb Polski - wersja 5 [Polish soil classification, fifth edition], 2011, Soil Science Annual. 62(3): 1-193.

Świtoniak M., Kabała C. \& Charzyński P., 2016, Propozycja anglojęzycznych nazw jednostek Systematyki gleb Polski [Proposal of English equivalents for the soil taxa names in the Polish Soils Classification]. Soil Science Annual 67(3): 103-116.

Świtoniak M., Mroczek P. \& Bednarek R., 2016. Luvisols or Cambisols? Micromorphological study of soil truncation in young morainic landscapes - Case study: Brodnica and Chełmno Lake Districts (North Poland). Catena 137: 583-595. 